\title{
Civil Service Reform in China: Impacts on Civil Servants' Behaviour*
}

\author{
John P. Burns and Wang Xiaoqi
}

\begin{abstract}
China's civil service reforms sought to improve the performance of civil servants by introducing more competitive selection processes, incentives to reward performance, and tightened monitoring and supervision. The impact of the reforms was undermined by clashes with other policies being implemented at the time and by a failure to address elements of organization culture that have rewarded various forms of illegal behaviour, such as corruption. Empirical material for our study is drawn from government data and the experience of civil service reform in three Chinese urban areas (Beijing's Haidian district, Changchun and Ningbo) since the 1990s.
\end{abstract}

Civil service reform is designed in part to affect the behaviour of government employees, and China's reforms were no exception. Dating from the 1980s and given a boost in 1993 with the promulgation of new regulations and in 2006 with the Civil Service Law, ${ }^{1}$ China's reforms introduced more competition, additional monitoring and performance-based rewards. The reforms were based on a logic that over-simplified the relationship between superiors and subordinates and left in place elements of an organization culture that condones illegal behaviour such as corruption.

The scholarly literature on China's civil service reforms has focused on description and analysis of changes to specific civil service regulations and norms, such as retirement, and to the processes of selection, appointment, training and dismissal. ${ }^{2}$ Scholars have also sought to analyse the socioeconomic factors that account

* We gratefully acknowledge the support of the Hong Kong Research Grants Council for this article.

1 See Ministry of Personnel, Guojia gongwuyuan zhidu zanxing tiaoli (Provisional Regulations on State Civil Servants) (Beijing: Ministry of Personnel, 1993). For the Civil Service Law in English, see the Ministry of Human Resources and Social Security website http://www.mohrss.gov.cn/mohrss/ Desktop.aspx?path=mohrss/mohrss/InfoView\&gid=33ade59a-f729-4cef-bac0-e2f94a1fed8d\&tid=Cms_ Info, accessed 14 April 2009.

2 On China's civil service regulations and the Civil Service Law, see Hon S. Chan and Edward Li Suizhou, "Civil service law in the People's Republic of China: a return to cadre personnel management," Public Administration Review, May/June 2007, pp. 383-98; Melanie Manion, Retirement of Revolutionaries in China: Public Policies, Social Norms, Private Interests (Princeton: Princeton University Press, 1993); Melanie Manion, "The cadre management system, post-Mao: the appointment, promotion, transfer and removal of Party and state leaders," The China Quarterly, No. 102 (1985), pp. 203-33; John P. Burns, "Strengthening central CCP control of leadership selection: the 1990 nomenklatura," The China Quarterly, No. 138 (1994), pp. 458-91.

(C) The China Quarterly, 2010 doi:10.1017/S030574100999107X 
for the mobility of Chinese officials. ${ }^{3}$ Few studies, however, have focused on the implementation of civil service reform and those that have offer conflicting interpretations of the impact of the reforms. Scholars such as Tsao and Worthley, ${ }^{4}$ Tong, Straussman and Broadnax, ${ }^{5}$ and Chan ${ }^{6}$ have evaluated the reforms positively, but have focused mostly on policies and process. Scholars such as Chou have compared the goals and results of reform and have found them wanting. Indeed, he refers to the reforms as an "implementation failure." We present a more mixed picture.

We focus on the impact of reform policies on the incentive structure for civil servants and on their behaviour. We start from the assumption that Chinese civil servants seek to maximize utilities such as power and income, and that the repertoire of civil servant behaviour is relatively wide, including working, shirking and sabotage. ${ }^{8}$ Working here means devoting effort towards accomplishing policy goals, while shirking means directing effort towards non-policy goals (such as watching DVDs, chatting online and monitoring the stock market when these activities are unrelated to the job). Sabotage means actively undermining policy goals, through acts such as delay, hindrance, bungling or obstruction. We see corruption which damages the government's reputation as a kind of sabotage, where civil servants either on their own or in collusion with superiors defraud the public, thus undermining the central government's stated goal of reducing or eliminating corruption. ${ }^{9}$

This article is based in part on fieldwork carried out in 2000-01 and 2004 in three urban areas that differ in their administrative rank, geographic location and level of economic development. Beijing's Haidian district 北京市海淀区 is a prefecture-level unit of the capital, a directly administered municipality, while Changchun 长春 and Ningbo 宁波 are vice-provincial-level cities. Changchun (population 3.5 million) in the less developed north-east is the

3 Andrew G. Walder, "Career mobility and the communist political order," American Sociological Review, Vol. 60, No. 3 (1995), pp. 309-28; Zhou Xueguang, "Partial reform and the Chinese bureaucracy in the post-Mao era," Comparative Political Studies, No. 28 (1995), pp. 440-68; Zhou Xueguang, "Political dynamics and bureaucratic career patterns in the People's Republic of China, 1949-1994," Comparative Political Studies, Vol. 34, No. 9 (2001), pp. 1036-62.

4 King K. Tsao and John Abbott Worthley, "Chinese public administration: change with continuity during political and economic development," Public Administration Review, Vol. 55, No. 2 (1995), pp. 169-74.

5 Caroline Haiyan Tong, Jeffrey D. Straussman and Walter D. Broadnax, "Civil service reform in the People's Republic of China: case studies of early implementation," Public Administration and Development, No. 19 (1999), pp. 193-206.

6 Hon S. Chan "The civil service under one country, two systems: the case of Hong Kong and the People's Republic of China," Public Administration Review, Vol. 63, No. 4 (2003), pp. 405-17.

7 Chou Kwok Ping, "Conflict and ambiguity in the implementation of the civil service reform in China, 1993-2000," unpublished Ph.D. dissertation, the University of Hong Kong, 2003; Chou Kwok Ping, "Civil service reform in China, 1993-2001: a case of implementation failure," China: an International Journal, Vol. 2, No. 2 (2004), pp. 210-34.

8 See John Brehm and Scott Gates, Working, Shirking, and Sabotage: Bureaucratic Response to a Democratic Public (Ann Arbor: The University of Michigan Press, 1999).

9 For a recent re-statement of this policy see "Premier outlines anti-corruption work; vows to build clean government," People's Daily online, 30 April 2008, at http://english.peopledaily.com.cn/90001/90776/ 90785/6401754.html, accessed 23 April 2009. 
poorest of the three places (annual per capita GDP 39,341 yuan in 2006) while Ningbo (population 2.2 million) in the south is the richest (annual per capita GDP 74,458 yuan in 2006). ${ }^{10}$ In 2007 Haidian's (population 2 million) annual per capita GDP was 64,988 yuan. ${ }^{11}$ The structure of their economies also varies. The tertiary sector is most developed in Beijing where it contributes about 71 per cent of GDP compared to 42 per cent and 40 per cent for Changchun and Ningbo respectively. Primary industry contributes most to Changchun ( 9 per cent of GDP) compared to 5 per cent in Ningbo and 1.25 per cent in Beijing. ${ }^{12} \mathrm{We}$ make no claim that the experience of our field sites is representative of the country as a whole. We chose them because we wanted to examine the impact of civil service reform in several urban contexts, but also because we had access to them. We find variation in the implementation of civil service reform in our field sites and speculate that the variation may be explained by proximity to power, level of economic development and historical circumstance.

In 2000-01 we interviewed a total of 90 officials in education and environmental protection bureaus and a selection of their clients (such as school principals for education policy and factory managers for environmental protection policy) in each place. We followed up with a second round of interviews of 52 officials in Haidian and Changchun in 2004. The interviews were designed to elicit perceptions of how well the bureaus were performing and to identify those factors (including civil service reform) that contributed to their performance. ${ }^{13}$ The interviewees who were civil servants were employed at district level in Haidian and at city level in the two cities. Our focus on education bureaus and environmental protection bureaus rather than town and township officials in our field sites may have biased the results even more towards urban concerns. Nevertheless, given the importance of cities and the trend towards increasing urbanization in China, the picture we present of the impact of the reforms, though quite limited, is still significant.

\section{The Political Context of Civil Service Personnel Decisions}

Civil service management in China is embedded in a system of one-party rule where the Chinese Communist Party (CCP) plays the leading role. Authorities have enshrined the long-standing principle that "the Party manages cadres" (dang guan ganbu 党管干部), including civil servants, in the law. According to the Civil Service Law, in effect from 2006, China's civil service system

10 These figures are for the urban area only. State Statistical Bureau of China, Zhongguo chengshi tongji nianjian 2007 (China City Statistical Yearbook 2007) (Beijing: Zhongguo tongji chubanshe 2008), p. 125.

11 Haidian dang'an guan (Haidian Archives), 2008 nian Haidianqu dashiji (Haidian memorabilia 2008), http://www.hdda.gov.cn/dsj/dsj2008_01.asp, retrieved 16 April 2009. Haidianqu zhengfu (Haidian District Government), Zonghe shili xianzhu zengqiang (Capacity has been Improved), http://www.bjhd. gov.cn/zt/hdqzzb/hdfc/hdfc_1/200903/t20090319_143727.htm, retrieved 16 April 2009.

12 China City Statistical Yearbook 2007, p. 133.

13 For details see the Appendix and Wang Xiaoqi, "China's civil service reform and local government performance: a principal-agent perspective," unpublished Ph.D. dissertation, the University of Hong Kong, 2006. The 2004 interviews focused on the implementation of civil service reform. 
shall conform to the guidance of Marxism-Leninism, Mao Zedong Thought (Mao Zedong sixiang 毛泽东思想), Deng Xiaoping Theory (Deng Xiaoping lilun 邓小平理论) and the important thought of Three Represents (san ge daibiao 三个代表), follow the basic line of the primary stage of socialism, observe the line and policies of the Communist Party of China on cadre matters and adhere to the principle that the Party exercises leadership over cadre matters. ${ }^{14}$

Civil service management policy is made by the CCP's Organization Department (OD) under the supervision of the Politburo and at the centre is implemented by the Ministry of Human Resources and Social Security (formerly the Ministry of Personnel), and in particular by the Ministry's civil service bureau. The OD tightly controls the Ministry through an eleven-member Party core group (dangzu 党组), by requiring that civil servants in the Ministry be Party members, and through a system of concurrent appointments at the leadership level that leaves the same individual holding leadership positions in both the Ministry and the OD. ${ }^{15}$ Similar interlocking arrangements link the personnel bureaus and organization departments of Changchun, Ningbo and Haidian district. ${ }^{16}$ Although nominally belonging to separate organizations, the Party and government for the most part operate in step on civil service management implementation matters. Conflicts occur, of course, but their locus is mostly within the Party (central-local tensions, conflicts among factions and so forth) ${ }^{17}$ rather than between "the Party" as an organization and "the government."

Civil service personnel decisions for non-leading positions in the civil service, including selection, appraisal and so forth (discussed below) are managed and approved by the Party core group within the relevant bureau under the supervision of the organization department at the same level. Leading positions are managed according to nomenklatura authority. ${ }^{18}$ Beginning in 1993 the CCP extended the "civil service system" of personnel management to many other organizations including the CCP itself and organizations on the Central Committee-controlled nomenklatura, such as mass organizations, the legislature, the Chinese People's Political Consultative Conference and the democratic parties. ${ }^{19}$ Interviews with

14 Civil Service Law, article 4.

15 See the Ministry of Human Resources and Social Security website http://www.mohrss.gov.cn/mohrss/ Desktop.aspx?PATH=/sy/leaders/YinWeiMin.

16 By 2009 none of Changchun, Ningbo or Haidian had merged their personnel and labour and social security bureaus.

17 See John P. Burns, "The Chinese Communist Party's nomenklatura system as a leadership selection mechanism: an evaluation," in Kjeld Erik Brødsgaard and Zheng Yongnian (eds.), The Chinese Communist Party in Reform (London: Routledge, 2006), pp. 33-58 for a discussion of conflict within the Party during the early 1950 s and the Cultural Revolution.

18 See, for example, Manion, "The cadre management system, post-Mao"; John P. Burns (ed.), The Chinese Communist Party's Nomenklatura System (Armonk: M.E. Sharpe, 1989); Burns, "Strengthening central CCP control of leadership selection"; Hon S. Chan, "Cadre personnel management in China: the nomenklatura system, 1990-1998," The China Quarterly, No. 179 (2004), pp. 703-34.

19 The system was extended to the CCP in 1993, the Youth League, the Women's Federation, the Song Qingling Foundation, the NPC Standing Committee bureaucracy, the CPPCC National Committee bureaucracy, the All-China Federation of Trade Unions, the Science and Technology Association, and the Returned-Overseas Chinese Federation in 1994, the Association of Taiwan Compatriots, the Huangpu Military Academy Alumni Association, the eight democratic parties and the All China 
mainland judges indicate that the judiciary and the procuratorate are also managed according to the civil service system. ${ }^{20}$

According to the Civil Service Law, Party membership is not a general requirement for becoming a civil servant. ${ }^{21}$ Nevertheless, the OD has determined that some civil service posts may be held only by Party members. The effect of this requirement is quite restrictive, especially for central-level posts. ${ }^{22}$ In recent years lists of positions and their requirements (indicating which posts are restricted to Party members) have been published on the government's website. In 2004 posts reserved for CCP members ( 38 per cent of a total of 1,041 vacancies on one list) tended to be in politically sensitive departments (most Central Committee departments, ${ }^{23}$ the State Council General Office, Ministry of Education, Ministry of Science and Technology, National Defence, National Minorities, Public Security, Family Planning, Securities Regulatory Commission, and the Stateowned Assets Supervision and Administration Commission) or in sensitive bureaus of ministries (the general office, policy and regulation, planning, personnel, education, social security, and public security). ${ }^{24}$ All civil service posts in the Ministry of Personnel were reserved for Party members, as were civil servants recruited into the personnel departments of all government agencies. ${ }^{25}$

The Party is spread more thinly at local levels. Even so, a locally focused list published online in 2009 reaffirms that sensitive positions in most civil servant-employing agencies are limited to Party members, including positions in personnel management, confidential document handling, investigations handling, Party work and sometimes financial administration. ${ }^{26}$ There appears to be a

footnote continued

Federation of Industry and Commerce in 1995, the All-China Federation of Literature and Art Circles, the All-China Writers' Association, the All-China Journalists' Association, the All-China Staff and Workers Political Thought Work Research Association, the service units (shiye danwei) of all local Party committees, the All-China Legal Studies Association, the All-China Association for Friendship with Peoples Overseas, the All-China Foreign Affairs Studies Association, the All-China International Trade Promotion Association, and the All-China Red Cross in 1996, and the All-China Disabled People's Federation, in 1997. See Ministry of Personnel (ed.), Renshi gongzuo wenjian xuanbian (Selection of Personnel Work Documents) (various volumes) (Beijing: Renshi chubanshe, various years).

20 Interviews with Supreme People's Court judges, Hong Kong, May 2001

21 See the Civil Service Law, article 11. In 1998, officials reported that $80 \%$ of civil servants were Party members. See Zhongguo jigou, No. 7 (1998), p. 4.

22 The policy in effect restricts entry to economically active Party members under the age of 28 who have a university degree.

23 In 2004 the CCP International Liaison Department sought 29 new people, and reserved only one of these positions for a CCP member. The other posts were for language translators. The Intellectual Property bureau was the largest hirer on the list (132 positions) and reserved only one (a personnel functionary) for a CCP member.

24 See "Zhongyang, guojia jiguan 2004 nian kaoshi luyong jiguan gongzuo renyuan he guojia gongwuyuan zhaokao jianjie" ("Recruitment brief for central and state organs recruiting organ work personnel and state civil servants"), 2004, Ministry of Personnel website http://www.mop.gov.cn, accessed 12 April 2004.

25 Ibid.

26 For a 2009 list see the Ministry of Human Resources and Social Security website http://www.mohrss. gov.cn/mohrss/gwy2009/UserControl/Student/StudentIndex.aspx, for a zip file of available posts 
good deal of variation, however. In some local customs bureaus few additional posts were reserved for Party members, while in Xiamen and Guangzhou virtually all the same posts were for CCP members only. Among local entry and exit quality inspection and supervision bureaus, only the Tianjin bureau required CCP membership for every available post. Shanghai and Guangzhou (and nearly all other local bureaus) made no such demand for the same job titles. We speculate that nearness to political power in the case of the entry and exit quality inspection and supervision bureaus was important (Tianjin is the closest port to Beijing), while a record of gross misbehaviour in the Xiamen and Guangzhou customs authorities may explain the more restrictive requirements there. Other variations are more difficult to explain. For example, out of 2,792 jobs available in "state" tax offices in various localities, only a handful required CCP membership. The same job title in one province required CCP membership but in another province did not. The effect of requiring Party membership for these jobs is, however, to restrict competition.

Our discussion of civil service reform should be seen within this context of tight Party control, restricted access and limited competition. We turn now to a discussion of selected reform policies and their impact on civil servants' behaviour.

\section{Civil Service Reform Policy and Implementation}

China's civil service reforms have been piecemeal and have resulted in new policies being laid over the existing Party-controlled cadre system, which was characterized by central planning, allocation of graduates to jobs through government-determined manpower plans, non-institutionalized performance appraisal and position-based pay. ${ }^{27}$ The system centrally managed all whitecollar workers across the economy using uniform policies, which created various inefficiencies and failed to provide motivation. China's civil service reforms were designed to improve the performance of government-employed administrators, managers and professionals.

Civil servants serve multiple principals, including their immediate superiors, local government, central government and the public. This discussion is organized around two particularly intractable problems for managers: hidden information problems (candidates for positions seek to hide information about their true intentions and/or abilities from their potential employers) and hidden action problems (civil servants seek to hide information about their performance from

footnote continued

dispatched by central state administrative organs, service units of State Council system subordinate units that implement the state civil service system, and "other posts." Accessed 14 April 2009.

27 See Doak A. Barnett, Cadres, Bureaucracy, and Political Power in Communist China (New York: Columbia University Press, 1967); Harry Harding, Organizing China: The Problem of Bureaucracy 1949-1976 (California: Stanford University Press, 1981); Lee Hong Yung, From Revolutionary Cadres to Party Technocrats in Socialist China (Berkeley: University of California Press, 1991). 
their superiors [immediate, local government and central government] and/or from the public). We discuss several types of reform policies on selection (a oneoff transitional selection in which cadres entered the new civil service, entry-level selection, selection on promotion), monitoring and supervision, performance appraisal, and performance-based rewards. A comprehensive discussion of civil service reform policies is beyond the scope of this article. ${ }^{28}$ We seek only to illustrate key strategies that the CCP has used to address these problems and their impact on the behaviour of civil servants.

\section{The Hidden Information Problem}

Reform policies have focused on attempts to discover more information about candidates' abilities, aptitudes and intentions, information which utility maximizing candidates might seek to hide from an employer. ${ }^{29}$ The reforms included two types of screening to reveal more information: a one-off exercise designed to screen out shirkers during the transition to the new civil service system, and regular screening associated with entry-level and promotion selection exercises.

In the mid to late 1990s a one-off exercise was carried out throughout the country to reveal under-performers. The government required current position holders to sit examinations to transfer to the new civil service within the first three years of the new arrangements. By September 1997, the expected completion date for establishing the new system, all provincial-level governments had reportedly complied, but only 85.4 per cent of prefecture-level governments, 55.4 per cent of county level governments and "some" town and township governments had completed the task. ${ }^{30}$

Data from our field sites indicate that many localities probably failed to screen out under-performers. In Beijing's Haidian district, for example, only 0.3 per cent of officials failed to be transferred to the new competitive service (see Table 1). In Ningbo city, apparently somewhat more discriminating, 97.6 per cent of 19,029 officials were screened in to the new service. ${ }^{31}$ Although authorities provided for a one-time only exercise, they probably failed to identify many underperformers. We suggest that informal norms that called on supervisors to take care of the welfare of co-workers undermined the reform. The decision to leave the screening method to the discretion of local governments ${ }^{32}$ may have enabled

28 For civil service reform policies see Chan and Li, "Civil service law in the People's Republic of China," pp. 383-98.

29 See Paul Milgrom and John Roberts, Economics, Organization and Management (Upper Saddle River, NJ: Prentice-Hall, 1992).

30 Chou Kwok Ping, "Civil service reform in China, 1993-2001,” p. 218.

31 Personnel Bureau of Ningbo City (ed.), Ningbo shi guanyu shixing guojia gongwuyuan zhidu de zicha baogao, (Internal Investigation on the Implementation of China's Civil Service System in Ningbo City) (Ningbo, 1999).

32 See Ministry of Personnel, Guojia gongwuyuan zhidu shishi fang'an (Implementation Plan of China's Civil Service Reform) (Beijing: Ministry of Personnel, 1994); Li Ruhai and Zeng Yuming, Ganbu xiang gongwuyuan guodu shiwu (A Practical Handbook of Civil Service Transition) (Beijing: China Personnel Press, 1994), p. 163. 
Table 1: Transfer Method, Beijing's Haidian District, 1997

\begin{tabular}{lrr}
\hline Action & Number & \multicolumn{1}{c}{$\%$} \\
Direct transfer (no exam) & 2,432 & 81.2 \\
Transferred through exam & 395 & 13.2 \\
Delayed transfer & 92 & 3.1 \\
Transferred through "administrative investigation" (shenpi 审批) & 68 & 2.1 \\
Failed to transfer & 9 & 0.3 \\
Total & 2,996 & 100.0 \\
Source: & & \\
$\quad$ Haidian District Personnel Bureau 1998. & &
\end{tabular}

supervisors to maintain social harmony at the expense of efficiency in the work place.

The timing of the one-off exercise also varied. Haidian, designated a "trial point" (shidian 试点) in civil service reform in 1992, completed all transition work by December 1996. ${ }^{33}$ The two cities started later (Changchun in November 1994 and Ningbo in July 1995) and not surprisingly completed later (Changchun in 1996, except for the police, and Ningbo in December 1998). ${ }^{34}$ Given Haidian's proximity to power we expected earlier compliance, even though its rank (prefecture-level) is below the rank of the other field sites. Implementation of civil service reform is usually a top-down exercise.

Officials set up an annual nationwide civil service entry-level selection system for undergraduates, postgraduates and "members of society." According to the process, candidates apply for a specific post (posts are now listed individually online). The employing agency checks that candidates have met the minimum requirements - such as age, educational level, gender in some cases, Party or youth league membership - and then sends those who qualify approval to sit the exam. The next stage involves more in-depth investigation of successful candidates, including interviews and perhaps specialist exams. The entire process is managed by the Party core group of the employing agency, implemented by the employing agency's personnel unit and overseen by the CCP organization department at that level. By 2009 more than 775,000 people were competing for some 13,500 centrally managed jobs, an indication of the competitive nature of the formal civil service selection process (see Table 2). Not surprisingly given the competition, authorities have uncovered cases of abuse (for example, officially over 1,000 cases of exam cheating in 2008 alone). ${ }^{35}$ They have increased

33 Personnel Bureau of Haidian District, Haidian qu guanyu guojia gongwuyuan zhidu zhifa jiancha de zicha baogao (Internal Investigation on the Implementation of the Civil Service System in Haidian District) (Haidian: 1998). Note that by 1997, 92 officials were permitted to delay transfer to the new system, presumably to permit them to become better prepared for the exam, or they were about to retire, or about to be transferred out.

34 Personnel Bureau of Ningbo City, Internal Investigation; Changchun Personnel Bureau (ed.), Changchun shi jigou gaige yu gongwuyuan zhidu gaige wenjian ziliao huibian (Collection of Documents on Changchun's Implementing Institutional Reform and Civil Service Reform) (Changchun, 1997).

35 South China Morning Post, 20 January 2009. 
evaluation of their performance, 31 were short-listed. The candidates visited a township within Beijing municipality and studied an exhibit that detailed the development of the township. They then wrote a paper analysing the township's development. Twelve candidates passed this stage and were interviewed by the Minister and several vice-ministers. In the interview, candidates were given a problem and 30 minutes to prepare to answer questions on how to handle it. The Party core group then selected four for promotion from among the eight who passed this stage. ${ }^{37}$ All candidates in this case were Party members in a process managed by the Party core group. Although such practices are probably most common at the central level, some kind of competitive promotion exercises have also been used by local governments. ${ }^{38}$

Authorities also carry out "peer evaluations" (minzhu pingyi 民主评议) and audits of previous performance to narrow the field in promotion exercises. ${ }^{39}$ We speculate that use of peer evaluations has undermined supervisory use of punishments, including dismissals, to control subordinate behaviour: from 1996 to 2003 authorities nationwide dismissed only about 2,000 civil servants each year. ${ }^{40}$ Because supervisors must go through peer evaluation in preparation for promotion, their subordinates become stakeholders. As a result, supervisors avoided using punishments for fear that their subordinates would renege during the peer evaluation. This may explain why institutionalized punishment practices have not constituted a real deterrent for subordinates since the government adopted peer evaluations.

China's reforms have been undermined from at least two sources. First, authorities demanded that local governments implement other policies that have negated or lessened the impact of the reforms. Beginning in 1998, for example, personnel authorities carried out a nationwide downsizing exercise that effectively prohibited many local governments from hiring recruits through the new competitive process. Our data show that education bureaus were affected by this campaign, which precluded them from recruiting new staff for much of the period reviewed here. ${ }^{41}$ Moreover, throughout the period central authorities required local governments to provide employment for demobilized soldiers who became civil servants without going through a competitive selection process. From 1998 to 2001 Haidian district government only recruited 24 new civil servants through the competitive system, but employed at least 215 demobilized

37 Personal communication from a participant, Beijing, 19 March 2004.

38 See Renmin news, http://edu.people.com.cn/GB/22223/3786292.html; http://www.2ed.cn/Article-52-8510. shtml; http://news.people.com.cn/GB/37454/37460/4956108.html; http://www.guangzhou.gov.cn/node_392/ node_393/node_398/2005-10/112942805473864.shtml, accessed 14 April 2007.

39 At local level, see Maria Edin, "State capacity and local agent control in China: CCP cadre management from a township perspective," The China Quarterly, No. 173 (2003), pp. 35-52.

40 Zhang Bolin, Tuijin ganbu renshi gongzuo kexuehua, minzhuhua, zhiduhua de zhongda jucuo (Great Measures to Make Cadre Personnel System more Scientific, Democratic and Institutionalized) from http://www.mop.gov. cn/Desktop.aspx?PATH=rsbww/sy/xxll\&Gid=36796243-b120-477e-9c3e-bcab0545fd88\&Tid=Cms_Info, accessed 7 April 2006.

41 See Wang Xiaoqi, "China's civil service reform and local government performance." 
Table 3: Demobilized Soldiers Transferred into Beijing's Haidian District, 1995-2001

\begin{tabular}{lcccccc}
\hline Year & $\begin{array}{c}\text { Total } \\
\text { number }\end{array}$ & Female & $\begin{array}{c}\text { Type of Employer } \\
\text { Party-state } \\
\text { organs }\end{array}$ & $\begin{array}{c}\text { Service } \\
\text { units }\end{array}$ & $\begin{array}{c}\text { Enterprises } \\
\text { New developing } \\
\text { area (shiyanqu } \\
\text { 试验区) }\end{array}$ \\
1995 & 66 & 25 & 26 & 21 & 3 & 16 \\
1996 & 96 & 37 & 48 & 20 & 8 & 20 \\
1997 & 111 & 48 & 69 & 22 & 3 & 17 \\
1998 & 137 & 58 & 69 & 37 & 12 & 25 \\
1999 & 187 & 80 & 45 & 95 & 16 & 31 \\
2000 & 178 & 64 & 61 & 78 & 3 & 0 \\
2001 & 97 & n.a. & 40 & 48 & 9 & 36 \\
Source: & & & & &
\end{tabular}

soldiers in various agencies (Table 3). From 1997 to 1999 Ningbo absorbed 1,273 demobilized soldiers into city, county and township government, who then made up about 6.9 per cent of Ningbo's civil service. ${ }^{42}$ Downsizing and accommodating demobilized soldiers stalled the implementation of a key civil service reform initiative.

An additional problem was the use by local governments of informal screening criteria to select civil servants, such as the ability to pay. Relatively large numbers of official positions, mostly at district and county levels, have been filled through corruption. ${ }^{43}$ In the late 1990 s, officials sold scores of government jobs in Wenzhou 温州 city, Zhejiang, Pizhou 䂙州 county, Jiangsu, Beihai 北海 city, Guangxi, Huaibei 淮北 city, Anhui, Tieling 铁岭 city, Liaoning, Guangfeng 广丰 county, Jiangxi, and in Heilongjiang province. ${ }^{44}$ Even central and

42 Personnel Bureau of Ningbo City, Internal Investigation.

43 For scholarly studies of corruption in China see Chan Kin-man, "Corruption in China: a principalagent perspective," in H.K. Wong and Hon S. Chan (eds.), Handbook of Comparative Public Administration in the Asia-Pacific Basin (New York: M. Dekker, 1999), pp. 299-324; Ting Gong, The Politics of Corruption in Contemporary China: An Analysis of Policy Outcomes (Westport, CN: Praeger, 1994); Ting Gong, "Jumping into the sea: cadre entrepreneurs in China," Problems of Post-Communism, Vol. 43, No. 4 (1996), pp. 26-34; Ting Gong, "Forms and characteristics of China's corruption in the 1990s: change with continuity," Problems of Post-Communism, Vol. 30 , No. 3 (1997), pp. 277-88; Ting Gong, "Corruption and local governance: the double identity of Chinese local governments in market reform," The Pacific Review, Vol. 19, No. 1 (2006), pp. 85-102; $\mathrm{Lu}$ Xiaobo, Cadre and Corruption: the Organizational Involution of the Chinese Communist Party (Stanford, CA: Stanford University Press, 2000); Melanie Manion, Corruption by Design: Building Clean Government in Mainland China and Hong Kong (Cambridge, MA: Harvard University Press, 2004); Sun Yan, Corruption and Market in Contemporary China (Ithaca, NY: Cornell University Press, 2004); Yong Guo, "Corruption in transitional China: an empirical analysis," The China Quarterly, No. 194 (2008), pp. 349-64.

44 Renmin ribao (People's Daily), 24 March 1998, in FBIS-CHI-98-097, 7 April 1998; China Daily in South China Morning Post, 22 September 1998; Xinhua, 29 October 1998, in FBIS-CHI-98-310, 6 November 1998; Sing tao jih pao (Sing Tao Daily) (Hong Kong), 13 May 1998, in FBIS-CHI-98-133, 13 May 1998; Ming Pao (Hong Kong), 28 October 1998, in FBIS-CHI-98-301, 28 October 1998; and Liaowang (Outlook), 10 March 1997, in FBIS-CHI-97-071, 10 March 1997. 
provincial-level leaders sold government posts. They included former National People's Congress vice-chairman Cheng Kejie 成克杰, executed in 2000 for corruption. $^{45}$ In June 2004 the former head of the Jiangsu provincial CCP Organization Department was dismissed for soliciting 100 million yuan in bribes from lower-ranking officials seeking promotion. ${ }^{46}$ Given the centralized nature of personnel decision making in China and that so senior an official in such a sensitive post was able to sell government posts for many years, it is likely that the practice was widespread throughout Jiangsu province. The former governor of Hubei province, Zhang Guoguang 张国光, was convicted in December 2004 of accepting more than 300,000 yuan for helping individuals win promotions in Shenyang 沈阳. In November 2004 a district head in Sichuan's Nanchong 四 川南充 city was dismissed for selling 61 departmental posts between 1999 and 2003. In March 2005 the former Party secretary of Heilongiiang's Suihua 绥化 city went on trial for accepting bribes from 18 people between 1992 and 2002 to secure their promotions. In all 260 officials were caught in this case. In May 2005 the Party secretary in charge of personnel in Guangdong's Heyuan 广东 河源 city was convicted of selling posts from 1992 to $2003 .{ }^{47}$ In these cases corrupt superiors sought not only to enrich themselves but also to recruit new subordinates into their corrupt enterprises.

Sun Yan suggests that the sale of government posts was particularly prevalent in poor areas where alternative income sources were scarce. ${ }^{48}$ This may have characterized the 1990s, but more recent data indicate that opportunity may also play a significant role. ${ }^{49} \mathrm{We}$ have identified certain functions the carrying out of which may have provided civil servants with opportunities to collect rents from the public, and thus to recoup the sums they paid for their position. We classify these as "wet" functions (Table 4). Civil servants know that in these positions they will be able to obtain a return on their investment in purchasing an office, the price of which we speculate varies depending on the income-earning power of the position, bid up perhaps by the increasing competition of the civil service reforms. ${ }^{50}$ Press reports indicate that a junior position in a city-level planning and resource bureau in Liaoning province in 2005 cost from 30,000 to 50,000 yuan. ${ }^{51}$ As Sun points out, if top leaders sell posts, as we speculate they do in "wet" agencies, they may use the more rigorous selection policies to obtain information on the willingness of candidates to engage in corrupt

45 See Wenhui bao [Hong Kong], 1 August 2000.

46 Qingdao News, http://www.qingdaonews.com/gb/content/2006-01/25/content_5949521.htm, accessed 13 April 2007.

47 Xinhua News, http://news.xinhuanet.com/legal/2004-02/24/content_1329525.htm; http://news.xinhuanet. com/newscenter/2004-11/10/content_2197953.htm; http://www.hlj.xinhuanet.com/zfzq/2006-03/23/ content_6553880.htm; http://news.xinhuanet.com/legal/2005-05/10/content_2939557.htm, accessed 13 April 2007.

48 Sun Yan Corruption and Market in Contemporary China, p. 146.

49 See Yong Guo, "Corruption in transitional China," p. 358, who argues that corruption reflects institutional loopholes and institutional failure.

50 We are grateful to a reviewer for suggesting this interpretation.

51 South China Morning Post, 25 March 2005. See also SCMP, 29 April 2005. 
Table 4: "Wet" Functions

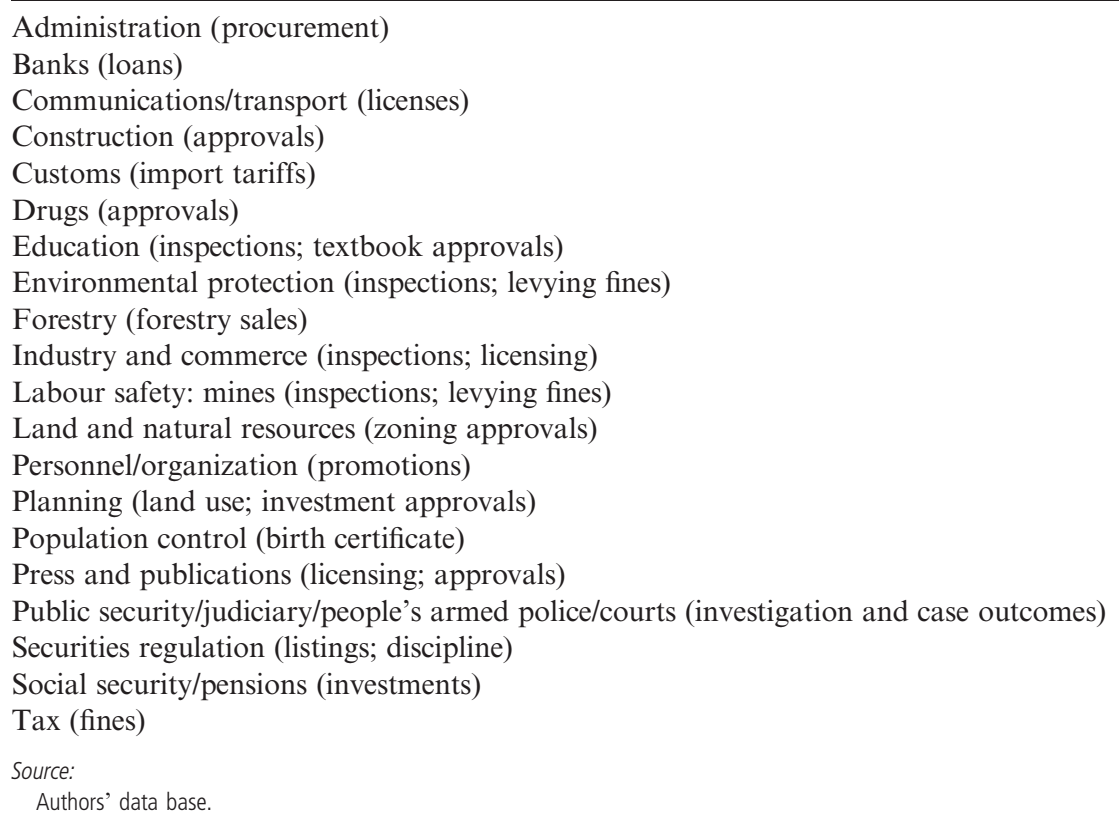

practices. In this kind of environment a more competitive civil service may actually drive the price of posts up, making corruption even worse.

The cumulative impact of these practices has meant that significant numbers continue to enter the civil service through non-competitive means. ${ }^{52}$

\section{The Hidden Action Problem}

Reformers have also sought to improve civil servants' performance through tighter monitoring and supervision, and attempting to align the incentive systems of superiors and subordinates in the pursuit of official policies. ${ }^{53}$ We argue that efforts to impose tighter discipline and control on civil servants have been relatively ineffective.

Civil service reform has focused on strengthening monitoring mechanisms. Such mechanisms include surveillance such as the "supervisor responsibility system” (shouzhang fuzezhi 首长负责制) and systems of reporting on the fulfilment (or not) of targets set for local government that cover a wide array of activities. ${ }^{54}$

52 A Ministry of Personnel staffer estimated that in 2002 some 38\% of new appointments came in through non-competitive means. Interview, 19 March 2004.

53 See Civil Service Law chapter 5 (Appraisal), chapter 9 (Disciplinary Action), articles 83 to 85 (Dismissal) and chapter 12 (Salary, Benefits and Insurance). Civil service management authorities share responsibility for monitoring and supervising civil servants with the CCP's disciplinary inspection commission system, audit, public security, the judiciary and the procuratorate.

54 Susan H. Whiting, Power and Wealth in Rural China: the Political Economy of Institutional Change (Cambridge: Cambridge University Press, 2000); Edin, "State capacity and local agent control." 
Monitoring systems also focus on individual performance. China's reforms have been characterized by formal improvements in these areas. As shown above, however, effective institutions to control the sale of government posts are apparently weak.

The widespread and endemic nature of corruption in China is an indication of the weakness of the civil service reforms monitoring and supervisory system. ${ }^{55}$ In the notorious Xiamen smuggling case, ${ }^{56}$ civil servants colluded with a corrupt businessman Lai Changxing 赖昌星 to defraud the public. Involved in this case were 360 Party and government officials, two at ministerial level, 26 at bureau level and 86 at division level. ${ }^{57}$ This extensive network of officials (mainly from the customs, public security, state security, local commodity inspection bureau and port administration, and some even from the military) took bribes from the smuggling group in exchange for approval and protection of the smuggling companies to get their goods into the country. The Xiamen scandal shows that corruption networks have been able to take over government agencies completely. Lai was known as "the underground director" of the Xiamen customs bureau, and his approval was necessary before promoting, removing or transferring officials within the customs office. Other smugglers even paid Lai a "customs inspection fee" so that their goods would not be detained by Xiamen customs or border control officials. ${ }^{58}$

Officials in our field sites were also corrupt. In 1999, the former Party secretary of Ningbo city, Xu Yunhong 许运鸿, was convicted of colluding with criminals and diverting public money for personal use. ${ }^{59}$ In 2004, Changchun authorities punished 1,250 officials for corruption. Of these, 52 were at or above division level: one at bureau level, five at deputy bureau level and 46 at division level. Fifty-four of the 1,250 received prison sentences and others had their administrative rank and Party membership removed. ${ }^{60}$ In 2007 Haidian district head, Zhou Liangluo 周良洛, was arrested for participating in illegal real estate deals. ${ }^{61}$ In this regard the experience of officials in our field sites was apparently not atypical.

Given the low probability of being prosecuted (from 1993 to 1998 fewer than half of the corruption cases being investigated led to criminal charges being filed and only 6.6 per cent of these led to officials being sentenced ${ }^{62}$ ), engaging in

55 See Manion, Corruption by Design; Yong Guo, "Corruption in transitional China."

56 See Shawn Shieh, "The rise of collective corruption in China: the Xiamen smuggling case," Journal of Contemporary China, Vol. 14, No. 42 (2005), pp. 67-91.

57 Zhang Xianhua et al., Feng bao: chachu xiamen teda zousi an jishi (Violent Storm: A Record of the Investigation and Prosecution of the Extraordinary Xiamen Smuggling Case) (Beijing: Zuojia chubanshe, 2001), p. 239.

58 Qin Jie, Zhai Wei and Wu Jing, "Justice forever prevails over evil - on investigations into Xiamen's sensational smuggling case (Parts 1, 2 and 3)," in FBIS-CHI-2001-0223, 25 July 2001.

59 See BBC News: http://news.bbc.co.uk/2/hi/asia-pacific/455942.stm, accessed 30 April 2007.

60 See: http://www.zxxw.gov.cn/donghk/htm/30/2005_2_25_3709.html, accessed 30 April 2007.

61 Caijing News, http://www.caijing.com.cn/newcn/home/todayspec/2007-04-15/17906.shtml, accessed 30 April 2007.

62 See Hu Angang, Zhongguo: tiaozhan fubai (China: Fighting Against Corruption) (Hangzhou: Zhejiang renmin chubanshe, 2001); Hu Angang in SCMP, 24 March 2001. 
corrupt practices appears to have been a fairly low-risk activity. Rational actors, observing that their peers were enriching themselves with relative impunity, would therefore be encouraged to do the same. In agencies where "wet" functions predominate we speculate that new inductees learned through imitation that corruption was acceptable behaviour. Informal norms that condoned corrupt behaviour perpetuated such behaviour. The reforms have clearly failed to put in place effective monitoring and sanctioning mechanisms.

Monitoring and sanctioning mechanisms may be less necessary where incentives are aligned between supervisors and subordinates in pursuit of official policy goals. ${ }^{63}$ We argue that for a variety of reasons the formal system of performancebased rewards introduced in the reforms was relatively ineffective at this kind of incentive alignment. Paradoxically, corruption opportunities have encouraged a perverse incentive alignment that allowed networks of superiors and subordinates to pursue their own private goals at the expense of the public.

Performance-based rewards can provide a key incentive for employees to work hard. ${ }^{64}$ Authorities have attempted to implement performance-based rewards at both the organization and individual levels. In Changchun in 2001, for example, city officials launched an annual exercise to rank all government bureaus according to various performance criteria. ${ }^{65}$ Bureau leaders understood that being ranked a "good" performer was beneficial to the bureau as a whole and to their own careers. Changchun education bureau leaders signed performance contracts with all administrative staff, promising a bonus to each staff member if the bureau could be among the top five in the city-wide competition. Targets were specified in the contracts and contracting parties were held personally responsible for achieving them. In 2003 the education bureau ranked third and its staff all received a bonus of 1,800 yuan. During interviews, officials revealed that they believed that rewards would follow their conscious efforts to work. It appears that in this case credible leadership encouraged civil servants to work hard.

Under the cadre system individual performance was formally assessed using politically oriented criteria, not work achievements. The reforms sought to refocus the evaluations on work performance. ${ }^{66}$ Although the regulations seem rational, we have found that the performance appraisals have been conducted in a highly pro forma manner. For example, civil service regulations permitted no more than 15 per cent of civil servants to be rated as "outstanding," a norm followed rigorously in our field sites ${ }^{67}$ In practice the classification of individual performance has turned the official four-grade system into a de facto two-

63 See Milgrom and Roberts, Economics, Organization and Management.

64 Ibid. Murray J. Horn, The Political Economy of Public Administration: Institutional Choice in the Public Sector (Cambridge: Cambridge University Press, 1995).

65 Interview, Changchun education bureau, 26 March 2004

66 Burns, "Changing environmental impacts on civil service systems"; Edin, "State capacity and local agent control."

67 In Changchun, for example, in 2000 and 2001 "outstanding" ratings went to $14.67 \%$ and $14.99 \%$ respectively. 
grade classification, with over 99 per cent of civil servants being rated "outstanding" and "competent" and thus receiving a bonus and pay rise. Given that most civil servants work in local government with limited opportunities for rewarding good performance, this may be rational supervisory behaviour.

Officially, two consecutive "incompetent" ratings should lead to dismissal. ${ }^{68}$ Because the consequences are so severe, few civil servants receive unfavourable performance ratings and less than 0.3 per cent nationwide were actually rated "incompetent." 69 Our fieldwork confirms that dismissals for those with poor ratings were rare. In Haidian if a civil servant was judged to be "basically competent" at an annual performance appraisal, he received 50 per cent of the original annual bonus. Those ranked as "incompetent" went through a probation period of from six to 12 months and received no bonus. From 1994 to 1998, in Haidian district government 34 people were ranked as "basically competent" and 24 as "incompetent" in annual appraisals. Only one person was dismissed as a result of failing the appraisal. Up to October 1998, no individual lodged an appeal regarding these results. ${ }^{70}$

In 1997 and 1998 in Ningbo only about 0.1 per cent of civil servants (numbering 28 and 39 individuals respectively) were assessed as "incompetent" in various city government bureaus. ${ }^{71}$ At the outset of reform in Changchun considerably more civil servants were evaluated as "incompetent" (0.4 per cent in 1995) than in either Haidian or Ningbo. Unusually, the Party in Changchun issued special regulations to punish poor performers that resulted in dozens of officials being dismissed in 1998 and 1999. ${ }^{72}$ We speculate that poorer Changchun, faced with very real downsizing targets and unable to transfer officials to other posts, used the appraisals to identify under-performers for dismissal and achieved a more efficient outcome, more in line with civil service reform objectives, than did either Haidian or Ningbo. Subsequently in Changchun the percentage rated "incompetent" fell to 0.14 per cent in both 2000 and 2001, closer to the norm..$^{73} \mathrm{We}$ find that the individual performance evaluation system introduced by the reforms as it has come to be practised has been relatively undiscriminating.

Structural constraints have impeded the attempts to align the incentives of supervisors and subordinates formally in the pursuit of official policy goals. First, nearly 60 per cent of civil servants are employed at county and township

68 Civil Service Law, article 83.

69 Interview, Ministry of Personnel, June 2002

70 Personnel Bureau of Haidian District, Internal Investigation.

71 Personnel Bureau of Ningbo City, Internal Investigation.

72 Changchun Local History Editorial Committee (ed.), Changchun nianjian 1999 (Changchun Yearbook 1999) (Changchun: Changchun Yearbook Press, 2000). The regulations required that every organization should report the civil servant who ranked lowest in the annual performance appraisal to its superior organization. In 1998, 44 civil servants were dismissed due to failing the appraisal. In 1999, 272 civil servants who ranked last in their organizations were reported to the Organization Department of Changchun Party Committee by various Party and government organs. Follow-up investigations were carried out on these cases. 91 of them received an administrative warning.

73 Changchun Local History Editorial Committee (ed.), Changchun nianjian 2000 (Changchun Yearbook 2000) (Changchun: Changchun Yearbook Press, 2001). 
levels where promotion opportunities are very few. ${ }^{74}$ The typical career ladder in a county, for example, where most officials could expect to spend their entire career, includes only five ranks (section member, deputy section head, section head, deputy county head and county head), far too few to provide motivation. Second, although there may be between ten and 14 pay steps for each rank, base pay differentials are very small, amounting to only a few tens of yuan per month. ${ }^{75}$ The formal career ladder in the local civil service is extremely compressed and base pay differentials very egalitarian, ${ }^{76}$ which gives supervisors little official leverage to reward performance

Given the structural problems (limited promotion opportunities) and the undiscriminating evaluation system, it will come as no surprise that implementing the formal performance-based reward system has had little impact. In our fieldwork we also found that although pay levels had increased overall (in line with official policy) civil servants did not perceive that pay was linked to performance (see Table 5). For example, 65 per cent of officials in environmental protection thought that pay was not linked to performance. The perception of a lack of a link was weaker in education, but still strong. Generally, officials in Changchun perceived less of a link between pay and performance than did those in Haidian. We speculate that the reform's official performance-based reward system has been undermined by the compressed structure of the local civil service and by an informal norm of egalitarianism. Supervisors empathize with their subordinates and value good co-worker relations. This is also the case if supervisors are colluding with them to carry out corrupt activities. We have indentified various "wet" functions that because of institutional failure encourage candidates to purchase offices in the knowledge that they will be able to recoup their investment when in office. We conclude, then, that the informal perverse system of aligning incentives in pursuit of private goals may have succeeded where the formal civil service reforms have not.

\section{Discussion}

Civil service reform policy required that newly hired civil servants be university graduates. In the 1980s and 1990s the educational profile of the civil service improved dramatically. ${ }^{77}$ Our fieldwork data are consistent with this trend. During 1991-2000 in Haidian, characterized by an overall decline in the number

74 Xi Liu, Zhongguo gongyuyuan zhidu (Chinese Civil Service System) (Beijing: Qinghua daxue chubanshe, 2002), p. 29. Xi reports that in 1998 there were 5.3 million civil servants in China. Chan and Li, "Civil service law in the People's Republic of China," p. 389 report that as a result of the expanded coverage of the civil service there are now about 6.3 million.

75 John P. Burns, "Civil service reform in China," in Governance in China (OECD, 2005), pp. 51-74.

76 John P. Burns, "Rewarding comrades at the top in China," in C. Hood and B.G. Peters (eds.), Reward for High Public Office: Asian and Pacific Rim States (London: Routledge, 2003), pp. 49-69.

77 CCP Organization Department, Dangzheng lingdao ganbu tongji ziliao huibian 1954-1998 (Collection of Statistical Information on Party and Government Leading Cadres 1954-1998) (Beijing: Dangjian duwu chubanshe, 1999). Many factors, including the expansion of higher education opportunities, contributed to this result. 
Table 5: Perception that Pay and Performance are Linked, Beijing's Haidian District and Changchun City (number of interviewees)

\begin{tabular}{lcr}
\hline & Yes & \multicolumn{1}{c}{ No } \\
Total education & $12(46 \%)$ & $12(46 \%)$ \\
Total environmental & $5(19 \%)$ & $17(65 \%)$ \\
Haidian education & $6(55 \%)$ & $4(36 \%)$ \\
Haidian environmental & $4(36 \%)$ & $6(55 \%)$ \\
Changchun education & $6(40 \%)$ & $8(53 \%)$ \\
Changchun environmental & $1(7 \%)$ & $11(73 \%)$ \\
Source: & & \\
$\quad$ Interviews, 2004. & &
\end{tabular}

Figure 1: Number of Civil Servants and their Educational Level in Beijing's Haidian District, 1991-2000

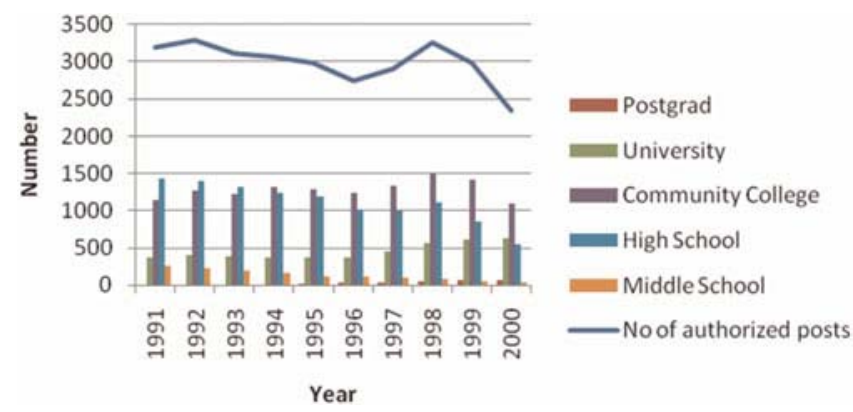

Source:

Interviews, Haidian district, 2001.

of authorized posts (except for 1996-98), the number of civil servants with high school qualifications declined, while the number of university graduates increased (Figure 1). During the same time the number of community college graduates pulled ahead of those with only high school credentials.

Similar trends are also clear in individual bureaus in our field sites. As Figure 2 shows, the number of staff with higher education (university degree) in the Ningbo education bureau increased from 50.7 per cent to 83.5 per cent from 1991 to 2000 . The largest jump in the number of university graduates employed occurred from 1995 to 1996, before the civil service system's more competitive hiring policies were formally implemented in Ningbo. As downsizing hit from 1998 onwards, the relative percentage of university graduates continued to grow. Data in both Figures 1 and 2 illustrate in stark terms the constraints the downsizing policy had on local government attempts to implement civil service reform.

As a result of more competitive selection processes employers now have additional information about candidates for jobs. These gains have been offset, however, by the weak monitoring and sanctioning system that has allowed the explosive growth of corruption and in particular the practice of selling 
Figure 2: Number of Civil Servants and their Educational Level in Ningbo Education Bureau, 1991-2001

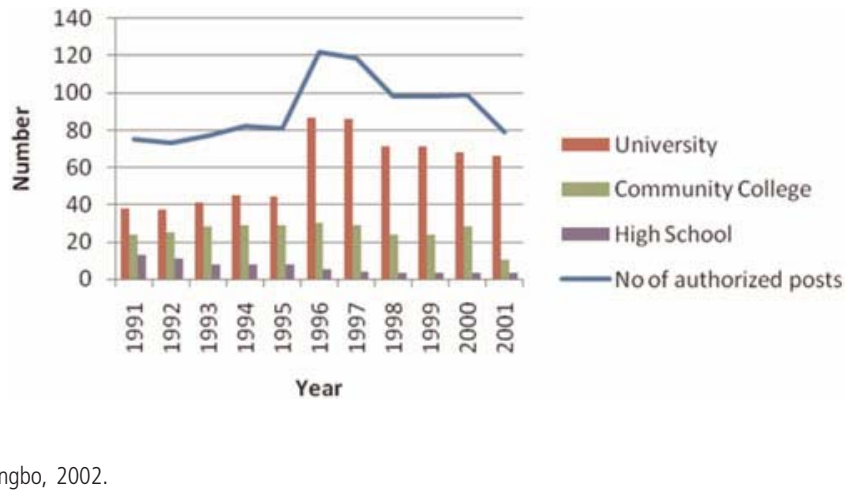

Interviews, Ningbo, 2002.

government posts. Structural factors and the operation of the formal reward and promotion system provide supervisors, especially at local level, with few legitimate levers for motivating subordinates. If performance-based rewards are not available officially, an alternative is promotion. ${ }^{78}$ As we have seen, especially at the local level promotion opportunities are severely restricted, which means that this lever is also not very effective. These structural factors and the ineffectiveness of the official performance-based system make the lure of corrupt opportunities to align incentives all the more appealing.

In our fieldwork interviewees perceived that performance in the bureaus was improving, which may mean that subordinates were increasingly hard working (Table 6). Our interviewees thought that civil service reform was less important for explaining bureau performance (the extent to which civil servants were hard working) than were other factors, especially leadership and financial resources. ${ }^{79}$ As shown above, credible leadership played a role in the implementation of an incentive aligning strategy in Changchun. These results are consistent with our argument that the impact of civil service reform per se on civil service behaviour has been modest.

The impact of reform has varied among our fieldwork sites. It is likely that given its proximity to power, Haidian felt confident about screening more of its cadres into the new civil service and it implemented the reforms earlier than did the others. Haidian, as a pilot within Beijing, opened up civil service posts to competition the earliest, followed by Ningbo and then Changchun. Differences in economic development may account for variation in the relative size and composition of various civil service agencies. Poorer Changchun appears to have been under-resourced compared to the other two places in our study

78 See Milgrom and Roberts, Economics, Organization and Management.

79 See Wang Xiaoqi, "China's civil service reform and local government performance." 
Table 6: Perception that Bureau Performance has Improved (\%)

\begin{tabular}{lrcrrrr}
\hline \multicolumn{3}{c}{ Environment } & & & Education \\
& Officials & Clients & \multicolumn{1}{c}{ Total } & Officials & \multicolumn{1}{c}{ Clients } & \multicolumn{1}{c}{ Total } \\
Beijing & $87.5(8)$ & $100.0(6)$ & $93.0(14)$ & $80.0(5)$ & $50.0(10)$ & $60.0(15)$ \\
Changchun & $87.5(8)$ & $90.9(11)$ & $89.5(19)$ & $100.0(6)$ & $100.0(7)$ & $100.0(13)$ \\
Ningbo & $100.0(6)$ & $100.0(10)$ & $100.0(16)$ & $100.0(7)$ & $66.7(6)$ & $85.0(13)$ \\
Note: & & & & & \\
$\quad$ Number in brackets is number of respondents. & & & & \\
$\quad$ Source: & & & & \\
$\quad$ Interviews, 2000-01.
\end{tabular}

which may have affected its capacity to implement civil service reform, and affected civil service staffing levels compared to population size in education and environmental protection. Nevertheless, Changchun used individual appraisals more effectively to rid the government of under-performers, especially in the early days of reform, perhaps because it had no option but to terminate their employment to meet downsizing targets.

The impact of the reforms in our fieldwork sites was also undermined by other policies being implemented at the time, such as downsizing and policies that required local governments to employ demobilized soldiers, and by widespread informal practices such as corruption. Education bureaus in our field sites which were relatively over-staffed at the start of the reforms (historical circumstance) were less able to benefit from more competitive hiring than were more recently set up environmental protection bureaus.

\section{Conclusion}

These very preliminary results serve as a useful reminder that implementing a complex policy, such as civil service reform, across a vast country like China is unlikely to be a uniform or problem-free exercise. The policy by its very design sought only limited increases in competition and failed to address organization cultures that condone illegal behaviour such as corruption.

\section{Appendix}

In 2000-01 we interviewed 40 officials from a pool of 388 (the administrative establishment of the three environmental protection bureaus was 30, 28 and 28 and the three educational bureaus was 148, 90 and 64 respectively in Beijing's Haidian, Ningbo and Changchun). We also interviewed 50 clients of government environmental protection services and education services. We conducted a total of 90 in-depth interviews, each lasting about 90 minutes, in July 2000, November 2000 and April-December 2001. A structured questionnaire was prepared for face-to-face interviews. 
78 The China Quarterly, 201, March 2010, pp. 58-78

Profile of Interviewees, 2000-01

Officials, $\mathrm{N}=\mathbf{4 0}$

Average age

Educational background

Bureaucratic rank

Clients of bureaus, $\mathrm{N}=\mathbf{5 0}$

Average age

Educational background

Occupation

\section{Characteristics}

41.64 years

University degree 27

Master's degree 2

Bureau chief/deputy chief 2

Division chief/deputy chief 16

Section chief/deputy chief 13

Section members 9

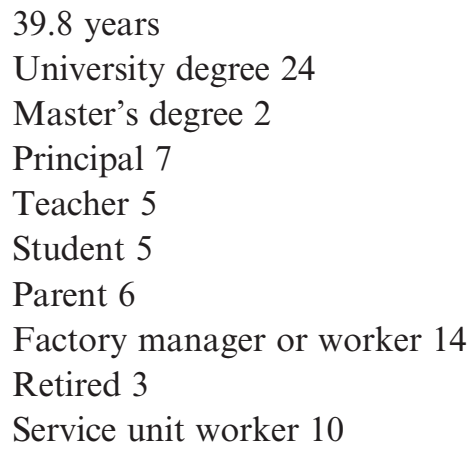

Teacher 5

Student 5

Parent 6

Factory manager or worker 14

Retired 3

Service unit worker 10

In March-April 2004, we carried out another round of in-depth interviews with officials in the bureaus of environmental protection and education in Beijing's Haidian and Changchun. The interviews were designed to elicit evaluations on local implementation of civil service reform. We conducted 22 interviews (11 in environmental protection and 11 in education) in Haidian and 30 interviews (15 in each bureau) in Changchun.

\section{Profile of Interviewees, 2004}

\begin{tabular}{ll}
\hline $\begin{array}{l}\text { Average age } \\
\text { Gender }\end{array}$ & 38.6 \\
& Male 29 \\
Education background & Female 23 \\
& Community college 6 \\
& University degree 39 \\
Master's degree 7 & Division chief 2 \\
Bureaucratic rank & Deputy division chief 5 \\
& Section chief 10 \\
& Deputy section chief 9 \\
& Section member 24 \\
NA 2 & 9.12
\end{tabular}

